\title{
Ormeloxifene in the management of dysfunctional uterine bleeding
}

\author{
L. Thulasi Devi ${ }^{1}$, Ravi Nimonkar ${ }^{2 *}$
}

\begin{abstract}
${ }^{1}$ Department of Obstetrics and Gynaecology, Command Hospital Eastern Command, Kolkata, West Bengal, India ${ }^{2}$ Department of Community Medicine, OC, SHO, Command Hospital Eastern Command, Kolkata, West Bengal, India
\end{abstract}

Received: 07 March 2018

Accepted: 03 April 2018

\section{*Correspondence:}

Dr. Ravi Nimonkar,

E-mail: ravinimonkar1175@gmail.com

Copyright: (c) the author(s), publisher and licensee Medip Academy. This is an open-access article distributed under the terms of the Creative Commons Attribution Non-Commercial License, which permits unrestricted non-commercial use, distribution, and reproduction in any medium, provided the original work is properly cited.

\section{ABSTRACT}

Background: Dysfunctional Uterine Bleeding (DUB), is the commonest cause of Abnormal Uterine Bleeding (AUB). It causes morbidity, anaemia, and unnecessary hysterectomies in women of fertile age group. This study attempts to study efficacy of medical management especially Selective Estrogen Receptor Modulator (SERM) namely Ormeloxefine (ORM) (Sevista $\left.{ }^{\circledR}\right)$ in Perimenopausal women. Ormeloxifene was marketed in India for contraception under brand names Centron, Saheli, Choice-7, Novex and Novex-DS. It's a benzopyran derivative also known as Centchroman which causes asynchronousity between ovulation and menstrual cycles possibly because of both estrogenic and anti-estrogenic actions. It has been known to cause delay in ovulation in clinical trials; however, majority have been unaffected. It causes delay in proliferation of endometrium thereby causing asynchronous cycles. It also improves motility of ciliary lining of Fallopian tubes thereby reducing the chances of implantation of fertilized egg.

Methods: This study is aimed at evaluation of subjective and objective stastical benefits and side effects in treatment of DUB in perimenopausal age group with ORM and commonly used 19 nortestosterone compound (progesterone); Norethisterone (NET).

Results: Primary outcome were analyzed at the end of every 3 months and at the end of one year finally. Secondary outcomes of the study in each arm were also assessed. There was stastically significant increase in $\mathrm{Hb}$ and stastically significant decrease in ET. Data analysis was done for variables in each arm by t-test to estimate the mean, median, range $\mathrm{P}$ and $\mathrm{t}$ value for a conclusion. Differences were taken as significant when $\mathrm{P}<0.05$.

Conclusions: ORM is a safe, cost effective, non-steroidal, non-hormonal drug with convenient dosage and better compliance for medical management of perimenopausal DUB with minimum focal pathology. Side effects observed need more evaluation with larger sample size to be statistically significant.

Keywords: Dysfunctional uterine bleeding, Ormeloxifene (Sevista®), Selective estrogen receptor modulator

\section{INTRODUCTION}

Dysfunctional uterine bleeding is one of the commonest conditions affecting all the ages of reproductive life, from puberty to menopause, and occasionally in postmenopausal women.

It is defined as abnormal bleeding from the uterus, which is unexplained on the basis of pregnancy, inflammation or neoplasm i.e. on careful bimanual pelvic examination no lesions of genital organs are detected. ${ }^{1,2}$

The two most important clinical features for diagnosis of Dysfunctional Uterine Bleeding are

- Abnormal Uterine Bleeding from corpus uteri which is acyclical, irregular in frequency, duration and volume with or without systemic symptoms. 
- Confirm absence of any pathology local or systemic that may cause menstrual abnormality.

Due to increasing awareness, more and more women are keen to preserve their menstrual function and often keen for a viable effective alternative to surgery. The present study proposes to see the effect of Ormeloxifene in patients of DUB and compare the results with the commonly used progesterone Norethisterone (NET).

\section{METHODS}

This prospective randomized study was conducted in Out Patient Department of Obstetrics and Gynaecology in a tertiary care hospital over a period of 2 years after due clearance was obtained from Ethical Committee to evaluate safety, efficacy, side effects, with stastical analysis in the medical management of DUB after obtaining due consent from patients. Study included 200 women with DUB in the perimenopausal age group between 41 to 50 years. 100 women were assigned in each arm of the study randomly. Primary outcome measures included Pictorial Blood loss Assessment Chart (PBAC), Menstrual Blood Loss (MBL), Menstrual Cycle (MC) pattern, Dysmenorrhoea, Haemoglobin (Hb), Endometrial Thickness (ET) by Trans Vaginal Sonography (TVS) and Hysteroscopy findings with Endometrial Biopsy (EB) by Dilatation and Curettage (D and C) at 3 monthly intervals or earlier if clinical findings demanded the investigation. Secondary outcome measures included compliance, acceptability, limitation of social activity, improvement in sexual activity, ability to maintain menstrual hygiene at a reasonable cost, need for other haemostatic agents, hospital admissions, surgical intervention, side effects, recurrence or worsening of symptoms in either group.

\section{Inclusion Criteria}

- Cases of Abnormal Uterine Bleeding with no organic/endocrinal pathology with normal hysteroscopy findings between the age group 41 to 50 years were included in the present study.

\section{Exclusion Criteria}

Patients with the following history/diseases were excluded from the present study:

- History of abortion within 3 months and childbirth within 1 year.

- Retained products of conception

- Past history of gestational trophoblastic neoplasia.

- Lactating mothers

- Genital prolapse

- Stress Urinary Incontinence

- History of vaginal mesh repair

- Intra Uterine Contraceptive Device /Oral Contraceptive Pill users.

- Patients with liver disorders and coagulopathies.
- Organic pathology of uterus

- Congenital anomalies of uterus

- Thyroid or endocrinological disorders

- Polycystic Ovarian Disease

- Malignancies

- Diabetes Mellitus

- Hypertension

- Smokers

- Those desirous of future pregnancies

- Autoimmune disorders

- Thromboembolic disorders

- Anticoagulant therapies

- Benign breast disease

\section{Study methodology}

The present study aimed to study the effectiveness of Ormeloxifene (SERM) and compare with commonly used progestin, a 19 nortestosterone compound Norethisterone in the relief of symptoms of Dysfunctional Uterine Bleeding. A total of 200 consecutive cases of Dysfunctional Uterine Bleeding reporting to GOPD, who have completed child bearing and above the age of 40 years fulfilling the above criteria were selected for this study. The subjects of mixed ethnicity were randomly grouped into the Ormeloxifene group and the Norethisterone group of 100 each with similar clinical presentations.

Initial evaluation was carried out by detailed history and clinical examination to rule out any systemic diseases, coagulation and liver disorders, diabetes mellitus and thyroid dysfunction. A detailed Gynecological and breast examination was carried out to rule out any pathology among the patients recruited for the present study. An initial haemogram, platelet levels, prothrombin time, liver function tests, baseline sugar levels and thyroid studies were performed to rule out bleeding disorders, liver dysfunction, diabetes and thyroid dysfunction. Pap Smear, Ultrasound (TVS) and Office Hysteroscopy were done to rule out any congenital malformation, fibroids, adenomyosis and other local causes for abnormal uterine bleeding in all cases. Before starting drug therapy, endometrium was obtained for histopathology and repeated after a course of drug therapy for six months and endometrium obtained after three months of drug free period to assess the efficacy of various treatment modalities. Endometrial thickness using Transvaginal Sonography was noted every 3 months to study response of the endometrium to the drug. The side effects and complications of the newer drug Ormeloxifene were noted and relief of symptoms and patient acceptability were compared with Norethisterone.

\section{Drug schedule}

Ormeloxifene is available in India as $60 \mathrm{mg}$ tablets ('Sevista ${ }^{\circledR}$ ' manufactured by Torrent Pharmaceuticals) and is already approved by Drug Controller of India. It 
has also been in use in India as Oral Contraceptive "Saheli" (Centchroman) without any major reported side effects in non-lactating and non-pregnant women. Since it affects fertility, women in the child-bearing age group desirous of future pregnancy were excluded from the present study.

Dosage administered was $60 \mathrm{mg}$ twice a week (Wednesday and Saturday) for 12 weeks followed by 60 mg once a week for next 12 weeks covering the entire duration of study. Norethisterone, a 19 nortestosterone compound (Primolut N) is a commonly used progestin used for treatment in Dysfunctional Uterine Bleeding.

Dosage administered was $10 \mathrm{mg}$ daily for 12 days in every cycle from fourteenth day of menstrual cycle. Anaemia was corrected with supplementary Iron therapy both Oral and Parenteral if indicated.

Only those patients who had been on regular prior follow up for at least three months with history of DUB uncontrolled by regular non-hormonal medication were recruited. Written consent was obtained, and a specific questionnaire based on community standards was prepared which was explained to them by Resident Gynaecologist.

\section{Data Analysis}

The observation so obtained was statistically analyzed and results compared for evidence-based conclusion.

\section{RESULTS}

Pictorial blood loss assessment chart (PBAC), by a Visual Analogue Scale (VAS); a method that correlates well with alkaline haematin test was used to measure the menstrual blood loss (MBL). The women were asked to use certain sanitary napkins which have been shown to have similar absorbent capacities.

Table 1: PBAC Scoring

\begin{tabular}{|lll|}
\hline Examination & Assessment & Score \\
\hline & Lightly soiled & 1 \\
\hline & Moderately soiled & 5 \\
\hline Clots & Saturated & 20 \\
\hline & Small & 1 \\
\hline
\end{tabular}

They recorded the number of napkins used each day and the degree of soiling of each pad used. Number and sizes of clots passed were also noted. Scores were assigned to different degrees of soiling of sanitary napkins and number and size of clots passed.

A PBAC score of upto 10 is scanty flow, 10-100 as moderate flow, 100-300 as heavy flow, more than 300 as excessive requiring definitive therapy and follow up.
PBAC more than 100 is blood loss greater than or equal to $80 \mathrm{ml}$ and was considered diagnostic of menorrhagia.

The main outcome measures were menstrual blood loss, blood haemoglobin levels and endometrial thickness in proliferative phase by Transvaginal Sonography.

Table 2: Relationship between parity and DUB

\begin{tabular}{|lll|}
\hline Parity & Number of cases & Percentage \\
\hline Unmarried & 16 & 8 \\
\hline Nullipara & 36 & 18 \\
\hline Para 1 & 24 & 12 \\
\hline Para 2-Para5 & 108 & 54 \\
\hline > Para 6 & 16 & 8 \\
\hline
\end{tabular}

Table 3: Pre-treatment Symptoms of DUB

\begin{tabular}{|lll|}
\hline Symptom & $\begin{array}{l}\text { Group A } \\
(\text { ORM) n =100 }\end{array}$ & $\begin{array}{l}\text { Group B } \\
\text { (NET) n=100 }\end{array}$ \\
\hline Menorrhagia & 44 & 48 \\
\hline Metrorrhagia & 46 & 45 \\
\hline Menometrorrhagia & 32 & 35 \\
\hline Intermenstrual bleeding & 8 & 4 \\
\hline Dysmenorrhoea & 21 & 24 \\
\hline Passage of clots & 46 & 43 \\
\hline Perimenopausal bleedin: & 12 & 10 \\
\hline
\end{tabular}

Women with two to five children were noted to have higher prevalence of DUB in this study.

Commonest menstrual symptom as per the questionnaire was Menorrhagia described as excessive bleeding during menstruation Out of three patients who showed endometrial hyperplasia, one patient of Norethisterone study group progressed to atypia after 3 months and she was taken up for hysterectomy.

Table 4: Objective parameters of pre-treatment clinical profile.

\begin{tabular}{|lll|}
\hline Variable & $\begin{array}{l}\text { Group A } \\
\text { (ORM) } \\
n=100 \\
(\text { mean) }\end{array}$ & $\begin{array}{l}\text { Group B } \\
\text { (NET) } \\
\text { n=100 } \\
\text { (mean) }\end{array}$ \\
\hline PBAC score & 369 & 382 \\
\hline Haemoglobin (gm\%) & 8.2 & 7.9 \\
\hline Endometrial Thickness $(\mathrm{mm})$ & 12.4 & 12.8 \\
\hline
\end{tabular}

Table 5: Histopathological pattern of Endometrium.

\begin{tabular}{|lll|}
\hline HPE TYPE & $\mathbf{n = 2 0 0}$ & Percentage \\
\hline Proliferative & 144 & 72 \\
\hline Early Secretory & 26 & 13 \\
\hline Mid Secretory & 18 & 9 \\
\hline Late Secretory & 9 & 4.5 \\
\hline Simple hyperplasia & 3 & 1.5 \\
\hline Atrophic & 0 & 0 \\
\hline
\end{tabular}


TVS measurement for ET for outcome measurement was done in Proliferative phase for all subjects. $64 \%$ of the subjects had moderate degree of anaemia as per WHO definition and iron supplementation was given to all patients.

Commonest side effect observed in ORM group was Oligomenorrhoea $(16 \%)$ and in NET group was cyclical mastalgia (18\%). GI symptoms like bloating, loss of appetite, nausea and constipation were commonly seen in NET group.

Table 6: $\mathrm{Hb} \%$ in gms and its distribution $(\mathrm{n}=200)$.

\begin{tabular}{|lll|}
\hline Hb \% in gms & Number of patients & Percentage \\
\hline$<6$ & 6 & 3 \\
\hline $6.1-8$ & 20 & 10 \\
\hline $8.1-10$ & 128 & 64 \\
\hline $10.1-12$ & 46 & 23 \\
\hline
\end{tabular}

Other side effects were cyclical mastalgia, headache and polyuria as seen in any physiological menstrual cycle. Side effects observed in ORM group mimicked menopausal symptoms like SUI, hot flushes, irritability and leg cramps.

There was significant improvement in haemoglobin $(\mathrm{Hb})$ from a baseline of $8.2 \mathrm{gm} \%$ to $9.45 \mathrm{gm} \%$ ( $\mathrm{p}<0.05$ ). PBAC score showed significant improvement from 369 to 107 $(\mathrm{p}<0.05)$.

All menstrual symptoms like number of bleeding days, dysmenorrhoea and passage of clots showed improvement which was statistically significant. TVS showed decrease in Endometrial Thickness. All calculation was done at baseline and final outcome at the end of one year. There was significant improvement in Haemoglobin levels, symptom of dysmenorrhoea and PBAC score in ORM and NET arm; $\mathrm{p}<0.05$.

Number of bleeding days, amount of flow, passage of clots and Endometrial Thickness by TVS also decreased in both arms significantly.

Amenorrhoea was noted in ORM arm at the end of 6 months and cyclical bleed was seen in NET arm as expected. Overall both arms showed stastically significant improvement in all subjective and objective outcome measurements (Table 8, 9, 10, 11).

All poor responders were further evaluated and one of the NET group showed Endometrial Hyperplasia with Atypia and underwent hysterectomy.

It's seen from the analysis that subjective and objective parameters improved in both arm of patients which is stastically significant in Ormeloxifene and Norethisterone.

Both drugs have an excellent safety profile; however convenience of dosage and compliance is better with Ormeloxifene. Amenorrhoea and absence of cyclical, regular menstrual bleeding every month is unacceptable to most and main reason for dissatisfaction.

Table 7: Assessment of Side effects in both groups.

\begin{tabular}{|lll|}
\hline Symptoms & $\begin{array}{l}\text { Group A } \\
(\mathbf{O R M})\end{array}$ & $\begin{array}{l}\text { Group B } \\
\text { (NET) }\end{array}$ \\
\hline GI symptoms & 0 & 7 \\
\hline Constipation & 2 & 13 \\
\hline Weight Gain & 2 & 12 \\
\hline Headache & 1 & 8 \\
\hline Oligomenorrhoea & 16 & 10 \\
\hline Menopause & 7 & 0 \\
\hline SUI & 2 & 0 \\
\hline Polyuria & 3 & 5 \\
\hline Prolapse & 1 & 0 \\
\hline $\begin{array}{l}\text { Cyclical } \\
\text { Mastalgia }\end{array}$ & 0 & 18 \\
\hline $\begin{array}{l}\text { Continuous } \\
\text { Spotting }\end{array}$ & 0 & 1 \\
\hline $\begin{array}{l}\text { Intermenstrual } \\
\text { Spotting }\end{array}$ & 1 & 8 \\
\hline Hot Flushes & 5 & 1 \\
\hline Leg Cramps & 3 & 1 \\
\hline Irritability & 2 & 11 \\
\hline Pain Abdomen & 5 & 6 \\
\hline Giddiness & 2 & \\
\hline & & 2 \\
\hline
\end{tabular}

Table 8: Objective outcome measurements after ORM at the end of 3, 6, 9 and 12 months (n=100).

\begin{tabular}{|lllllll|}
\hline Variable (Mean) & Baseline & 3 & 6 & 9 & 12 & Mean post treatment \\
\hline Haemoglobin $(\mathrm{gm} / \mathrm{dl})$ & 8.2 & 8.8 & 9.6 & 9.8 & 9.6 & $(\uparrow) 9.45$ \\
\hline PBAC (score) & 369 & 105 & 67 & 105 & 107 & $(\downarrow) 96$ \\
\hline ET(TVS) (mm) & 12.4 & 10.8 & 6.4 & 7.2 & 7.8 & $(\downarrow) 8.05$ \\
\hline Bleeding days & 11 & 5 & 2 & 3 & 5 & $(\downarrow) 3.75$ \\
\hline Dysmenorrhoea & 21 & 5 & 7 & 7 & 8 & $(\downarrow) 6.75$ \\
\hline Passage of clots & 46 & 18 & 4 & 6 & 10 & $(\downarrow) 9.5$ \\
\hline Poor responders & - & - & - & - & 29 & \\
\hline
\end{tabular}


Table 9: Stastical analysis of Ormeloxifene arm (reference value at the end of 12 months).

\begin{tabular}{|c|c|c|c|c|c|c|c|}
\hline ORM & SD & Confidence & t value (n) & t value (n-1) & PTDIST & P value & Inference \\
\hline HB & 0.443 & 0.086 & 28.216 & 28.409 & 0.011 & $<0.05$ & $\mathrm{~S}$ \\
\hline PBAC & 19.356 & 3.793 & 141.041 & 140.215 & 0.002 & $<0.05$ & $\mathrm{~S}$ \\
\hline ET & 1.92 & 0.376 & 22.656 & 22.538 & 0.014 & $<0.05$ & $\mathrm{~S}$ \\
\hline MB days & 1.5 & 0.293 & 48.333 & 48.333 & 0.006 & $<0.05$ & $\mathrm{~S}$ \\
\hline DYS & 1.258 & 0.246 & 113.275 & 113.095 & 0.002 & $<0.05$ & S \\
\hline Clots & 6.191 & 1.213 & 58.956 & 58.681 & 0.005 & $<0.05$ & S \\
\hline
\end{tabular}

$\mathrm{df}=1, \mathrm{CI}=95 \%$

Table 10: Objective outcome measurements after NET at the end of 3, 6, 9 and 12 months (n=100)

\begin{tabular}{|lllllll|}
\hline Variable $($ Mean $)$ & Baseline & 3 & 6 & 9 & 12 & Mean post treatment \\
\hline Haemoglobin $(\mathrm{gm} / \mathrm{dl})$ & 7.9 & 8.5 & 9.3 & 10.2 & 9.8 & $(\uparrow) 9.45$ \\
\hline PBAC $($ score $)$ & 382 & 113 & 107 & 152 & 166 & $(\downarrow) 134.5$ \\
\hline ET(TVS) $(\mathrm{mm})$ & 12.8 & 11.4 & 10.8 & 11.2 & 11.4 & $(\downarrow) 11.2$ \\
\hline Bleeding days & 12 & 7 & 5 & 7 & 9 & $(\downarrow) 7$ \\
\hline Dysmenorrhoea & 24 & 7 & 5 & 7 & 9 & $(\downarrow) 7$ \\
\hline Passage of clots & 43 & 21 & 07 & 12 & 26 & $(\downarrow) 16.5$ \\
\hline Poor responders & - & - & - & - & 32 & \\
\hline
\end{tabular}

Table 11: Stastical analysis of Norethisterone arm (reference value at the end of 12 months)

\begin{tabular}{|c|c|c|c|c|c|c|c|}
\hline NET & SD & Confidence & t value (n) & t value $(n-1)$ & PTDIST & P value & Inference \\
\hline $\mathrm{HB}$ & 0.732 & 0.143 & 21.174 & 21.232 & 0.015 & $<0.05$ & $\mathrm{~S}$ \\
\hline PBAC & 28.965 & 5.677 & 85.447 & 84.963 & 0.003 & $<0.05$ & $\mathrm{~S}$ \\
\hline ET & 0.282 & 0.055 & 56.737 & 57.142 & 0.005 & $<0.05$ & $\mathrm{~S}$ \\
\hline MB days & 1.632 & 0.319 & 30.637 & 30.487 & 0.01 & $<0.05$ & $\mathrm{~S}$ \\
\hline DYS & 1.632 & 0.319 & 104.166 & 103.65 & 0.003 & $<0.05$ & $\mathrm{~S}$ \\
\hline Clots & 8.582 & 1.682 & 19.808 & 19.698 & 0.016 & $<0.05$ & $\mathrm{~S}$ \\
\hline
\end{tabular}

$\mathrm{df}=1, \mathrm{CI}=95 \%$

\section{DISCUSSION}

Literature on the use of Ormeloxifene in gynaecological diseases is very limited and is currently restricted to use in DUB by very few researchers. An overview of Phase III trials in India proved its efficacy in the treatment of DUB. ${ }^{3}$ Hence we selected this drug and compared with the commonly used progesterone NET.

The endometrial abnormality found is of 3 main types-

1. Ovulatory endometrium-

- Irregular ripening of endometrium

- Irregular shedding of endometrium

- Secretory endometrium (Normal).

2. Anovulatory-

- Proliferative

- Hyperplasia

3. Atrophic

4. Unusual types

PALM-COEIN classification for etiology of Abnormal Uterine Bleeding in women of reproductive age group in the absence of pregnancy. ${ }^{3}$
- $\quad$ Heavy Menstrual Bleeding (AUB/ HMB)

- Intermittent Menstrual Bleeding (AUB/IMB).

Table 12: PALM-COEIN classification for etiology of abnormal uterine bleeding.

\begin{tabular}{|c|c|}
\hline PALM (structural causes) & $\begin{array}{l}\text { COEIN } \\
\text { (nonstructural } \\
\text { causes) }\end{array}$ \\
\hline Polyp (AUB-P) & Coagulopathy (AUB-C) \\
\hline Adenomyosis (AUB-A) & $\begin{array}{l}\text { Ovulatory Dysfunction } \\
\text { (AUB-O) }\end{array}$ \\
\hline $\begin{array}{l}\text { Leiomyoma Submucosal } \\
\text { leiomyoma (AUB-LSM) }\end{array}$ & \multirow{2}{*}{ Endometrial (AUB-E) } \\
\hline $\begin{array}{l}\text { Other leiomyoma (AUB- } \\
\text { LO) }\end{array}$ & \\
\hline \multirow[t]{2}{*}{$\begin{array}{l}\text { Malignancy and } \\
\text { Hyperplasia (AUB-M) }\end{array}$} & Iatrogenic (AUB-I) \\
\hline & $\begin{array}{l}\text { Not yet classified } \\
(\text { AUB-N) }\end{array}$ \\
\hline
\end{tabular}

Principles of Management in DUB is first to arrest the bleeding, correct haemodynamic instability if present and correct anaemia. The diagnosis of DUB is by process of 
exclusion and every attempt should be made to exclude organic pelvic pathology and rule out pregnancy related bleeding.

Treatment is individualized according to-

- $\quad$ Age and parity

- The severity and duration of bleeding

- Degree of anaemia

- Nature of the underlying defect

Treatment modalities

Here we shall discuss the role of progesterone and SERM principally.

\section{Hormone Therapy}

As DUB is usually associated with hormonal disturbances its treatment with hormones has got an important role in its management. As large number of DUB patients are having anovulation or corpus luteal deficiency as its cause, progesterone is preferred to estrogen.

In patients wanting contraception or patients with contraindication to antifibrinolytics such as renal failure, oral contraceptives would be the agents of choice. Combined oral contraceptive pills (COC) act by probably inducing endometrial atrophy. ${ }^{4}$

The endometrial thickness is less than in a ovulatory cycle and there is less proliferation of glandular epithelium so the amount of blood loss is also less at the time of menstrual shedding. ${ }^{5}$

\section{Role of progestational agents-norethisterone}

Progesterone - The introduction of potent orally active progesterone has revolutionized the treatment of DUB. Unlike oestrogen the different synthetic progestational agents have different effects. In particular 19-Nortestosterone derivatives have an androgenic effect and appear to be more effective in controlling DUB. Progestational agents are used in 3 ways to treat the DUB

- To stop the episode of bleeding i.e. medical curettage, Albright, 1953. ${ }^{6}$

- Cyclical therapy throughout menstrual cycle form 5 th to 25 th day of menstruation.

- Cyclical in 2nd half of cycle from 20th to 25th day.

\section{Treatment modalities}

- Hormone therapy.

- SERM in the management of DUB

Selective Estrogen Receptor Modulators are a new category of therapeutic agents that bind with high affinity to estrogen receptors and mimic the effect of estrogen in some tissues but act as estrogen antagonists in others. ${ }^{7}$

One of the most obvious examples of SERM is the hormone estrogen. Since the interaction of any particular estrogen with the ER will result in a unique set of molecular responses, it is not unreasonable to assume that the clinical effects of one estrogen will differ in some way from other estrogen and from those of other SERMs. ${ }^{8}$

The action of SERMs on the vascular endothelium probably explains decrease in blood loss in DUB and improvement in the symptoms. ${ }^{9}$ It is known to have antiproliferative action on endometrium and breast tissue also.

Other clinical use of SERMs

\section{Indications}

- Contraception

- Prevention and treatment of Osteopenia and Osteoporosis.

- Reduction in breast cancer risk

- Dyspareunia

- DUB

- Vaginal dryness

- Decreases cholesterol

- Cyclical mastalgia and benign breast disorders.

\section{Side effects}

Stroke, venous thromboembolism, vaginal dryness, muscle spasms, aggravation of vasomotor symptoms, diaphoresis, prolonged QTc interval, sudden cardiac death, endometrial cancer, ovarian cancers and seizures.

Table 13: Classification of SERMs

\begin{tabular}{|ll|}
\hline $\begin{array}{l}\text { Pharmacological } \\
\text { group }\end{array}$ & $\begin{array}{l}\text { Generic drug } \\
\text { Clomiphene, Tamoxifen, } \\
\text { Triphenylethylene } \\
\text { derivatives }\end{array}$ \\
$\begin{array}{l}\text { Toremifene, Ospemiphene } \\
\text { (1271a), Droloxifene, } \\
\text { Idoxifene, TAT-59,GW5638 }\end{array}$ \\
\hline $\begin{array}{l}\text { EM-800,EM-652, Raloxifene, } \\
\text { Other nonsteroidal } \\
\text { compounds }\end{array}$ & $\begin{array}{l}\text { Arzoxifene, } \\
\text { LY353381 (SERM 3), LY } \\
\text { 357489. }\end{array}$ \\
\hline Naphthalenes & Lasofoxifene (CP 336,156) \\
\hline Benzopyrans & $\begin{array}{l}\text { ORMELOXIFENE, } \\
\text { Levormeloxifene, } \\
\text { EM-800(SCH 57050) }\end{array}$ \\
Findoles & $\begin{array}{l}\text { Pipendoxifenes (ERA-923), } \\
\text { Bazedoxifenes (TSE-424, } \\
\text { WAY-140424) }\end{array}$ \\
\hline Steroidal compounds & IC1182, 780 (Fulvestrant) \\
\hline
\end{tabular}


In conclusion, although SERMs were initially developed as antiestrogens for treatment of breast cancer, their unusual properties have led to their use in the prevention and treatment of other disease as well.

Drugs that reduce menopausal symptoms preserve bone, reduce cholesterol, and yet block the effects of estrogens on epithelial cells in the breast and uterus are theoretically possible to develop, and, when available, will provide a dramatic new paradigm for maintaining the health of women.

\section{Structure of ormeloxifene}

Ormeloxifene is a benzopyran SERM with specific action on estrogen on uterus. It is a trans 7-methyl 2, 2dimethyl 3 phenyl-4(4-(2-pyroldinoethoxy) phenylchroman hydrochloride which acts by tissue selectivity by different DNA transcriptions in different tissues. ${ }^{10} \mathrm{It}$ can be easily stored and has a long shelf life. After administration of single $60 \mathrm{mg}$ oral dose of the drug the concentration of the drug in serum at 30 minutes raised $63 \mathrm{ng} / \mathrm{ml}$ and peak of $125 \mathrm{ng} / \mathrm{ml}$ was achieved in 4 hours. Ormeloxifene is white to off-white power, having m.p. of 163 OC to $1660 \mathrm{C}$ and mol. Wt. Of 493.5 I.U. Ormeloxifene is very stable under normal conditions of storage and a suitable assay method has been standardized. The biological effect of Ormeloxifene has been explained on the basis of its pharmacological profile. It has been found to be a weak estrogen agonist and a potent antiestrogen. The terminal disposition halflife of the drug was calculated to be about $170 \mathrm{hrs}$ approximately equal to a week hence the weekly schedule of the drug after attaining a steady level of the drug in blood.

It blocks the cytosol receptors by its competitive binding over estradiol. It has mild estrogenic activity on vagina bone mineral density, CNS and lipids. ${ }^{11}$ It has been used in India successfully for many years as an Oral Contraceptive Pill Centchroman, Saheli. The drug is primarily a potent estrogen antagonist; however it has a weak agonist activity. The drug demonstrates a suppressive or a stimulatory effect on gonadotrophin release based on milieu interior. It is a potent antiproliferative agent in breast tissue. Levormeloxifene is the active enantiomer of Ormeloxifene.

Chronic use upto 4 years have been performed with no evidence of common, serious adverse events and no serious ovarian pathology. Benefits of this drug are that it decreases total cholesterol, LDL cholesterol by about 20\%-30\%. Endometrial thickness increases significantly without significant endometrial proliferation. ${ }^{12}$

The preclinical trial was undertaken using dose of 6.25 , $12.525 \mathrm{mg} / \mathrm{kg}$ of Ormeloxifene on Rhesus monkeys for a period of 12 months. Ormeloxifene caused no significant effect on total pituitary gonadotrophins. The drug causes amenorrhoea, as its common side effect, which is opposed to abnormal excessive bleeding that characterizes DUB The drug thus, can normalize the abnormality locally at the level of uterine endometrium without affecting hypothalamo-pituitary-ovarian axis. ${ }^{13,14}$ The presence of the benzopyran group in Ormeloxifene defines its receptor binding ability (RBM) and estrogen agonistic activity. Hence, this strategy has resulted in the development of a pharmacological model that attributes the differences in effects on the uterus. Ormeloxifene is therefore an optimally designed SERM that antagonizes the effects of estrogen on uterine and mammalian tissues due to presence of the basic side chain and while mimicking the effects of estrogen on bone and CVS. ${ }^{15,16}$

In summary, an ideal therapy for perimenopausal women will be one that prevents bone loss, has a positive effect on the cardiovascular system, and provides no risk of breast or uterine, cancer. Selective estrogen receptor modulators in general and Ormeloxifene in particular fits this profile. The present study aimed to study the efficacy of Ormeloxifene and compare the drug with Norethisterone in the management of DUB. Ormeloxifene is a better drug as compared to NET for relief of menstrual symptoms. We found Ormeloxifene and NET both to significantly reduce symptom of dysmenorrhoea. There was significant reduction in the passage of clots with Ormeloxifene compared to NET. There was stastically significant improvement in objective blood loss as measured by PBAC score with Ormeloxifene in cases of DUB. Ormeloxifene group was associated with statistically significant reduction in Endometrial Thickness after 6 months of therapy and three months follow up. ${ }^{17}$

We are of the opinion that Ormeloxifene is a better drug than Norethisterone in management of patients with Dysfunctional Uterine Bleeding and recommend that further trials should be carried out in younger age group to confirm / refute the side effects of Genital prolapse and Stress Urinary Incontinence before the drug is universally recommended for use. Presently we recommend the use of the drug only in patients who have completed child bearing in the perimenopausal age group after thorough investigations. The drug may be used as a first line of therapy in the medical management of DUB in this subgroup of patients.

Number of patients in this study group was small. Larger study groups with RCT and more stastical tests may be applied for reliable study outcome. Long term follow up of patients is required. Only perimenopausal age group included in view of fertility issues. Effect on other organs with Estrogen Receptors was not evaluated and is strongly recommended.

\section{Funding: No funding sources Conflict of interest: None declared}

Ethical approval: The study was approved by the Institutional Ethics Committee 


\section{REFERENCES}

1. Boshier and Liggins, 1974: Proceedings of the 5th Asia Oceania Congress of Endocrinology, P-18. The Endocrine Society of India, Chandigarh, as quoted by Dewhurst.

2. Southam AL and Richart RL. Prognosis for adolescents with menstrual abnormalities, Am J of Obstet and Gynec. 1966;94:637.

3. Chandra BS, Kumar SS, Shankar BT, Chandra RG, Chandra RA, Prasad KS. Ormeloxifene A Selective Estrogen Receptor Modulator, for the treatment of Dysfunctional Uterine Bleeding. J Obstet Gynaecol, Ind. 2004:56-9.

4. Brenner PF. Proceedings of symposium: 'Women with bleeding disorders and role of obstetrician and gynaecologists'.43 ${ }^{\text {rd }}$ Annual meeting ACOG, AJOG1996;175:761-2.

5. Shaw RW. Assessment of medical management of menorrhagia. BJOG.1994;101:15-8.

6. Mishell DR Jr. Non Contraceptive health benefits of oral steroidal contraceptives. AJOG. 1971;110:71320.

7. Albright AD, Weeks SR, Duffy MJ. Abnormal uterine bleeding: diagnosis and medical management. Prog Obstet Gynaecol. 1953;12:30926.

8. Enmark E, Gustafsson JA. Estrogen receptors an overview. J Intern Med. 1999;246:136-8.

9. Riggs BL, Hartmann LC. SERMs: Mechanisms of action and application to clinical practice. $\mathrm{N}$ Engl $\mathrm{J}$ Med. 2003;348:618-29.
10. Baker VL, Leitman D, Jaffe RB. SERMs in reproductive medicine and biology. Obstet Gynecol Surv. 2000;55:521-47.

11. Dutertre M,Smith CL. Molecular mechanisms of SERMs action, J Pharmacol Exp Ther 2000;295:4317.

12. Alexandersen P, Riis BJ, Stakkestad JA, Delmas PD, Christiansen C. Efficacy of levormeloxifene in the prevention of postmenopausal bone loss and on lipid profile compared to low dose HRT. J Clin Endocrinol metab 2001;86:755-60.

13. Osborne CK, ZhaoH, Fuqua SA. SERMs: structure, function and clinical use. Clin Oncol. 2000;18:317286.

14. Yaffe K. Estrogens SERMs and dementia: What is the evidence? Ann NY Acad Sci. 2001;949:215-22.

15. Jordan VC. Antiestrogens and SERM as multifunctional medicines. Clinical considerations and new agents. J Med Chem. 2003;46:1081-111.

16. Katzenellenbogen BS, Sun J, Harrington WR, Kraichely DM, Ganessunker D, Katzenellenbogen JA, et al. Structure-function relationships in estrogen receptors and characterization of novel SERMs with unique pharmacological profiles. Ann NY Acad Sci. 2001; 949:6-15.

17. Shia Shalen, Rumack CM, Wilson SR, Charboneau JW. The uterus and adnexa. In-Diagnostic Ultrasound $2^{\text {nd }}$ ed, New York, 1998;1:519-73.

Cite this article as: Devi LT, Nimonkar R. Ormeloxifene in the management of dysfunctional uterine bleeding. Int J Reprod Contracept Obstet Gynecol 2018;7:1885-92. 